HAMAR ANNA ${ }^{1}$

ROMÁNIAI VÁNDORMUNKÁSOK ÉS ÁTTELEPÜLTEK A KERTÉSZETI IDÉNYMUNKA PIACÁN²

DOI: 10.18030/SOCIO.HU.2017.3.47

\title{
ABSZTRAKT
}

Az empirikus kutatás eredményeire támaszkodó tanulmány a nemzetközi migrációhoz kapcsolódó mezőgazdasági idénymunkával foglalkozik. Bemutatja a romániai munkaerőpiaci migrációs trend hatását az idénymunkások mozgását biztosító hálózatok kialakulására, a munkaerő etnikai és társadalmi összetételének változására és a hálózatok részben differenciálódására, részben meggyengülésére. A kilencvenes években gyökerező, a változásokhoz alkalmazkodó stabil hálózatok fennmaradásukat a szelekciós mechanizmusuk változásának és a munkaszervezetbe betagozódni képes munkások eltérő formájú megtartásának köszönhetik. Az instabil hálózatokban mozgó vándorló munkások felett a munkaerőgondokkal küzdő termelők nem vagy alig rendelkeznek ellenőrzéssel, így folytatódik a foglalkoztató számára értékes munkavállalói kör kiválasztása. Az ezredforduló óta a migráns idénymunkások száma folyamatosan csökken, a hálózatok erodálódása megállíthatatlan, azonban a romániai napszámosok a munkaerőhiányos térségekben továbbra is a termelés fontos szereplői maradnak.

Kulcsszavak: agrárfoglalkoztatás, migráció, patrónus-kliens, romák

ROMANIAN MIGRANT LABOURERS AND RESETTLEMENT: THE SEASONAL AGRICULTURAL MARKET

ABSTRACT

This paper focuses on seasonal agricultural labour as part of transnational migration based on empirical research. It presents the effects of Romanian labour market migration on creating networks for seasonal labourers' mobility, on the transformation of the ethnic and social composition of the labour force, as well as on the differentiation and weakening of networks. The survival of networks has stabilized since the 1990 s. This can be traced back to the transformation of their selection mechanisms and the variety of ways employed to retain those workers that were capable of integrating into the work organisation. Producers experiencing labour force shortages have no control over workers in unstable networks, thus the selection of valuable employees continues. The number of migrant seasonal workers has declined since 2000, and the erosion of networks is inevitable. However, Romanian day-labourers are still important actors in regions suffering from labour force shortage.

Keywords: agricultural employment, migration, agricultural seasonal work, patron-client, Roma

1 Tudományos munkatárs, MTA Közgazdaság- és Regionális Tudományi Kutatóközpont Regionális Kutatások Intézete.

2 A tanulmány a Földből élők: agrárszereplők, vidéki fejlődési pályák és vidékpolitikák Magyarországon (OTKA 100675, témavezető: Kovács Katalin) kutatás keretében készült. 
HAMAR ANNA

\section{ROMÁNIAI VÁNDORMUNKÁSOK ÉS ÁTTELEPÜLTEK A KERTÉSZETI IDÉNYMUNKA PIACÁN}

\section{BEVEZETÉS}

A nyolcvanas évek második felétől a kilencvenes évek végéig a környező országokból Magyarországra irányuló migráció etnikai jellege - döntőrészt romániai magyar nemzetiségű menekültek, majd a bevándorlók érkezése - elfedte a területi mozgás gazdasági motivációit. A közös nyelv, etnikai hovatartozás, a kilencvenes évek elejére kialakuló magyarországi kapcsolati hálózatok csökkentették a munkavállalási migráció költségeit (Gödri 2010, Fox 2005, Pulay 2005, Sik 1996). A munkavállalás a magasabb jövedelem elérését, a család életkörülményeinek javítását, társadalmi státuszának megőrzését vagy emelését jelentette a migránsok számára, még akkor is, ha csak a másodlagos munkaerőpiacon jelenhettek meg (illegális) munkavégzéssel (Gödri 2004, Bodó 2009). Az ezredfordulótól a (kettős) állampolgárság lehetősége, a magyar munkaerőpiac megnyitása ellenére a magasabb bérezést nyújtó EU országok munkahelyeinek elérhetősége jelentősen csökkentette a romániai magyar munkaerő-migráció intenzitását.

Az Unió magállamainak (EGK) agráriumában a 60-as években elindult lassú folyamatok vezettek az átalakuláshoz, a foglalkoztatás szerkezetének változásához és a külföldi munkások alkalmazásához (Martin 1985, 2003, Andrzejewska-Rye 2012, Migrant 2013). Ezzel szemben a magyar mezőgazdaságban robbanásszerű volt a változás: a piacgazdaságba belépő, tulajdon- és birtokviszonyaiban, üzemszervezetében széttöredezett, újraszerveződő mezőgazdasággal magas munkanélküliség társult. A kilencvenes években formálódó magyar mezőgazdasági idénymunkapiac meghatározó szereplői voltak a romániai vendégmunkások. Idővel jelenlétük, a munkaerőpiacra gyakorolt befolyásuk drasztikus mértékben visszahúzódott, azonban az alföldi térségek egy részében még napjainkban is ők jelentik a napszámosok fő bázisát a „speciális atipikus foglalkoztatási sajátosságokkal" (Hárs 2013:61) jellemezhető mezőgazdaságban, különösen a magas élőmunka igényű zöldség- és gyümölcskertészetben. A napszámosok alacsony bérért, munkaidőhöz és munkahelyhez rugalmasan alkalmazkodva, legtöbbször szerződés nélkül (de nem szükségszerűen feketén) dolgoznak, és gyengén integrálódnak a munkaerőpiacra, de a termelésben stratégiai jelentőséggel bírnak.

Kiemelkedő szerephez jutottak a migránsok mozgását, munkavállalását biztosító, hálózatba szerveződő személyközi kapcsolatok, melyekben csak a migránsok, azaz a célországban élő migránsok, valamint az otthoni (potenciális) migránsok vesznek részt.

Jelen tanulmányban a munkavállalói migráció kevésbé ismert területével, a mezőgazdasági idénymunkások migrációjával foglalkozom. Arra keresek választ, hogyan szerveződtek a munkavállalói hálózatok, milyen szelekciós szempontok a meghatározók, és idővel ezek milyen változáson mentek keresztül. Választ keresek arra a kérdésre is, milyen munkavállalói csoportok mozognak a hálózatokban, és az utóbbi években már mérsékelt intenzitású migrációs trend hogyan befolyásolta az idénymunkások összetételét, helyzetét. 
A tanulmány első két részében a rendelkezésre álló statisztikai adatokra és szakirodalomra támaszkodva mutatom be az idénymunkások migrációjának fő vonásait. A harmadik rész termelőkkel és munkásokkal készített interjúkon alapul, és a hálózatokkal, valamint a napszámosok helyzetével foglalkozik.

\section{Módszertani megjegyzések}

Az agrárium átalakulásával foglalkozó, 10 térségre kiterjedő OTKA kutatás keretében készült tanulmányhoz az interjúkat 2014 és 2016 között Dél-Pest megye zöldség-gyümölcs kultúrájú, tanyás településein (egy mezőváros és három falu) készítettem. A termelői interjú az üzem szerkezetével, múködésével és fejlesztési törekvéseivel foglalkozott, érintve a foglalkoztatás kérdését. A munkásokkal készített interjúban az idénymunka vállalásáig tartó útra, jelenlegi helyzetükre és jövőbeli céljaikra kérdeztem rá. A tizenkét termelővel a gazdaságban, a nyolc munkással otthonaikban folytatott beszélgetés négyszemközt vagy a rokonok jelenlétében zajlott.

Az interjúzást akadályozta a külterületen vagy az egykori zártkertben, „szállásokká” átalakított házakban elhelyezett munkások nehéz elérhetősége: a napszámosokhoz csak a termelőkön keresztül vezetett az út. A legtöbb termelő nem járult hozzá napszámosaik megkereséséhez, hivatkozva a sok munkára, vagy tartottak attól, hogy a kérdezőt hatósági embernek tartván a vendégmunkások elhagyják a gazdaságot. Így a potenciális interjúalanyok száma nagyon korlátozottá vált. A magyar nemzetiségűek és a roma nők szívesen vállalták az interjút. A roma férfiak csak azért, mert tudták, hogy a termelő segítségével/hozzájárulásával értem el őket. Nyílt interjúmegtagadással nem találkoztam, a munkások különböző technikával lehetetlenítették el az interjúkészítést. Volt magyar nemzetiségű nő, aki „igen-nem” vagy tőmondatos válaszokkal védekezett az interjú ellen, a román anyanyelvű, de magyarul is beszélő roma napszámos „elfelejtett” magyarul, vagy lemondták az interjút és az időpontot a bizonytalan jövőbe helyezték, elérhetetlenné válva. Négy napszámos tért ki így az interjúkészítés elől, melyet a kiszolgáltatottságukból eredő félelemmel és bizalmatlansággal magyarázok.

Mind a négy településen készült interjú a termelőkkel, de csak két faluban és a mezővárosban értem el a napszámosokat.

\section{FOGLALKOZTATÁS ÉS MIGRÁCIÓ A HAZAI ÉS NEMZETKÖZI ADATOK TÜKRÉBEN}

Ebben a fejezetben az agrárfoglalkoztatás szerkezetének átalakulásával és a külföldi munkavállalók, ezen belül a mezőgazdasági idénymunkások foglalkoztatásban betöltött helyével foglalkozom az elérhető statisztikai adatok felhasználásával.

A szerkezeti átalakulásra, az Unió 28 tagállamával való összehasonlításra a három évente ismétlődő gazdaságszerkezeti összeírások adatai adnak lehetőséget. ${ }^{3}$ 2003-ban 69,5 ezer fő dolgozott időszaki ${ }^{4}$ munkásként a magyar mezőgazdaságban, az összes fizetett munkaerő 39,9 százaléka. 2013-ban a gazdaságszerkezeti összeírás már 128 ezer főt regisztrált, ők alkották a munkaerő 56,8 százalékát. 5

3 A 2016. évi gazdaságszerkezeti összeírásban előzetes, a munkaerőre még nem teljes körű adatok jelentek meg (lásd Statisztikai Tükör 2016. november 22.). A 2016. évi ország szerinti összeírások eredményeit még nem közölte az EUROSTAT.

4 Az időszaki alkalmazott statisztikai fogalom. Az agrárösszeírások meghatározása szerint az időszaki alkalmazottak az állandó alkalmazottaktól eltérően nem végeznek heti rendszerességgel, egy éven keresztül munkát a gazdaságban. Munkavégzésük szezonális jellegű (betakarítás, metszés stb.). (Útmutató a kérdőív kitöltéséhez, valamint Fogalomtár, GSZÖ, 2013. KSH, Budapest)

5 A munkaerő-felmérés adatainak elemzése szerint az ágazatok közül a mezőgazdaság foglalkoztatott legnagyobb arányban alkalmi 


\section{1. ábra. Időszaki alkalmazottak munkaerő-felhasználása (ÉME) az EU 28-ban az összes munkaerő arányában, 2013 (\%)}

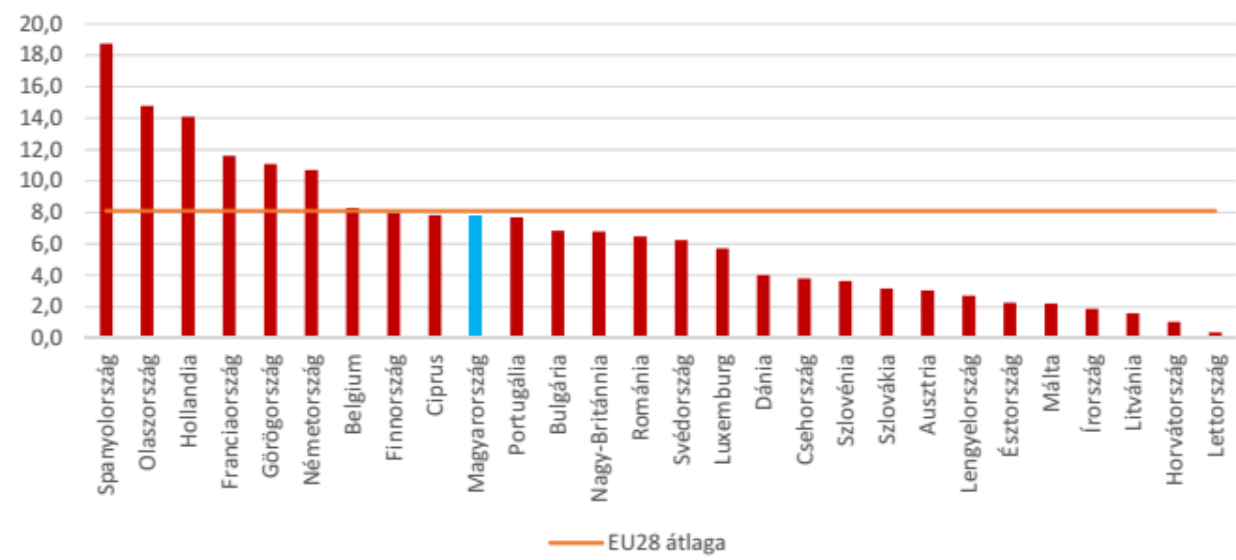

Forrás: Eurostat ${ }^{6}$

Szerepüket a termelésben jobban érzékelteti munkateljesítményük, 2003-ban munkavégzésük közel 15 ezer fö, 2010-ben már 20,5 ezer fö, 2013-ban 33,7 ezer fő fóállású, nyolc órában foglalkoztatott alkalmazott teljesítményének felelt meg. ${ }^{8}$ Az ágazat munkateljesítményén belüli arányuk az EUROSTAT adatai szerint 2003ban 2,8 százalék, hét évvel később 4,8 százalék volt, 2013-ban már 7,8 százalék. Itt kell megjegyezni, hogy a mezőgazdaságban végzett összes munka mennyisége tartalmazza az önellátó gazdaságok - az összeírt gazdaságok 59 százaléka! - adatait is, így a bérmunkások tényleges szerepe az árutermelésben nagyobb, mint ahogy arra az adatok következtetni engednek.

Az időszaki foglalkoztatás aránya 2013-ban elérte az EU28 átlagát (8,1 százalék), mely a szerkezetátalakulás folyamatainak felgyorsulását jelzi.

Az időszaki alkalmazottak létszámadata - elvben - tartalmazza a migráns munkavállalók munkavégzését is, azonban erre vonatkozóan nem rendelkezünk adatokkal. ${ }^{9}$

A migráció dinamikájában bekövetkezett változás nem hagyta érintetlenül a külföldiek számára munkát biztosító gazdasági ágazatok szerkezetét sem. A vendégmunkást foglalkoztató ágazatok közül előtérbe kerültek a szolgáltatás és a termelő ágazatok, legkisebb vonzerővel a mezőgazdaság rendelkezett és ez nem változott: a mezőgazdaságban mindössze a külföldiek 1,2 százaléka dolgozik (Hárs 2010). A vendégmunkások száma folyamatosan emelkedett a kilencvenes években, majd az évezred fordulóján a növekedés megtorpant, és Magyarország, valamint Románia EU-csatlakozásával, az EU-országok munkaerőpiacának könnyebb elérhetőségével, a magasabb kereset reményében egyre kevesebb román állampolgár vállalt munkát Magyarországon (Hárs 2010).

munkásokat, arányuk 1993-2010 közötti időszakban négy-öt százalék között ingadozott, mely egybecseng a gazdaságszerkezeti összeírás adataival. (lásd Hárs 2012).

6 http://ec.europa.eu/eurostat/statistics-explained/index.php/Farm_structure_survey_2013_-_main_results

7 A munkaerő teljesítmény (ÉME) egy fóállású, napi nyolc órában foglalkoztatott alkalmazott éves teljesítményének, legalább évi 1800 órának felel meg.

8 A létszámadatok forrása a KSH gazdaságszerkezeti összeírás megfelelő kötetei, a munkateljesítményre vonatkozó adatok az EUROSTAT adatbázisából származnak.

9 Az összeírás feltételezése szerint az összes az üzemben dolgozott időszaki alkalmazott számát megadják a termelők, azonban ennek kicsi a valószínúsége. 
1. táblázat. A szezonális munkavállalási engedéllyel rendelkező külföldi munkavállalók száma (fö)

\begin{tabular}{|c|c|c|c|c|c|c|c|c|}
\hline \multirow[t]{2}{*}{ Állampolgár } & 2006 & 2007 & 2008 & 2009 & 2010 & 2011 & 2012 & 2013 \\
\hline & \multicolumn{8}{|c|}{ év } \\
\hline Román & 1897 & 580 & 249 & & & & & \\
\hline Ukrán & 284 & 303 & 358 & 276 & 437 & 380 & 165 & 273 \\
\hline Összes & 2216 & 907 & 651 & 366 & 447 & 380 & 170 & 280 \\
\hline \multicolumn{9}{|c|}{ az összes arányában } \\
\hline Román & 85,6 & 63,9 & 38,2 & & & & & \\
\hline Ukrán & 12,8 & 33,4 & 55 & 75,4 & 97,8 & 100 & 97,1 & 97,5 \\
\hline
\end{tabular}

Forrás: Külföldi állampolgárok magyarországi munkavállalásának fő sajátosságai

(éves jelentések), NFSZ

A vendégmunkások számának apadása nem hagyta érintetlenül a mezőgazdaságot sem. A Nemzeti Foglalkoztatási Szolgálat (továbbiakban NFSZ) jelentése szerint 2009-ben a mezőgazdasági munkát vállaló összes vendégmunkás száma 4712 fő volt, 2013-ra számuk kétharmaddal, 1598 főre csökkent, majd 2016-ban 1789 főre emelkedett. A kismértékű emelkedést a termelők nagyobb bejelentési ${ }^{10}$ fegyelmének tulajdoníthatjuk és nem a migráns munkavállalók számának növekedésének. ${ }^{11}$

A romániai mezőgazdasági idénymunkások számának apadása már az ezredfordulón elkezdődött, és a munkaerőpiaci migrációs trend változását (Kiss 2010, Németh-Csite-Jakobi 2009) jelzi a 2006-2008 közötti időszakban végbement változás, a munkások létszámának közel 90 százalékos csökkenése.

Az NFSZ adataiból kirajzolódó képet a vendégmunkások szerepének radikális csökkenéséről alátámasztják az egyszerúsített foglalkoztatás ${ }^{12}$ adatai is. 2013 szeptemberében - a legnagyobb idénymunkák idején - a Nemzeti Vám- és Adóhivatalnál bejelentett 75 ezer mezőgazdasági idénymunkás alig több mint egy százaléka (919 fő) volt külföldi állampolgár, az általuk ledolgozott napok aránya pedig még az egy százalékot sem érte el (0,9 százalék)! Szeptember hónapban átlagosan két nappal kevesebbet dolgoztak, mint a hazai napszámosok, és 10 ezer forinttal volt alacsonyabb a keresetük. Marginális helyzetüket tükrözi munkateljesítményük nagysága is, mely 25,5 fő főállású, egész évben nyolcórás munkaviszonyban foglalkoztatott munkaerő teljesítményének felel meg.

A romániai vendégmunkások a migrációs centrumnak számító Közép-magyarországi régióban koncentrálódnak, általában a Szeged-Kecskemét-Cegléd-Budapest tengely menti települések elérhető munkahelyei

10 2009-től a román állampolgárságú migránsok munkavállalási engedély nélkül dolgozhattak, csak a munkaadó volt köteles bejelenteni a foglalkoztatást az NFSZ-nek.

11 Tényleges növekedést az a 110 (magyar nemzetiségú ukrán és szerb állampolgárságú) munkavállaló biztosíthatta, akik 2016. december 31-én érvényes munkavállalási engedéllyel dolgoztak az ágazatban.

12 A fekete foglalkoztatás kifehérítését szolgálta az alkalmi munkavállalói kiskönyv (AMK) (1997. évi LXXIV törvény), mely nem váltotta be a hozzá fúzött reményeket. 2010-ben lépett életbe az egyszerúsített foglalkoztatás rendszere (2010. évi LXXV. törvény), mely a mezőgazdasági idénymunkák mellett magába foglalja az alkalmi, a turisztikai, valamint a filmstatiszta munkavégzést is. A foglalkoztatási forma kiterjed a külföldi állampolgárokra is, évi 120 nap foglalkoztatást engedélyez, a legalacsonyabb bért a minimálbér 85 százalékában határozza meg. A mezőgazdasági idénymunkáknál a foglalkoztató összes bérre rakódó terhe naponta és napszámosként 500 forint közteher, szerződést akkor köteles kötni, ha azt a munkavállaló kéri. A bejelentett munkavállaló a foglalkoztatása alatt nyugellátásra, baleseti egészségügyi szolgáltatásra és álláskeresési ellátásra szerez jogosultságot, de nem minősül a TBJ szerint biztosítottnak. 
mellett döntenek (Németh-Csite-Jakobi 2009, Kincses 2012). A mezőgazdasági idénymunkások térbeli mozgásában a központi régió csak másodlagos célpont. Az NFSZ adatközlése szerint 2013-ban a Dél-alföldi régió gazdaságai kötötték le legnagyobb arányban a munkaerőt, a bejelentett foglalkoztatás több mint hetven százalékát ebben a régióban biztosították. A régión belül is kiemelkedik az élőmunka-igényes intenzív mezőgazdaságú Bács-Kiskun megye. Feltűnő a legnagyobb zöldség- és gyümölcstermelő Szabolcs-Szatmár-Bereg megyében a romániai napszámosok rendkívül alacsony jelenléte, melyet a nagyszámú hazai - és létszámában fogyatkozó, illegálisan foglalkoztatott ukrajnai magyar nemzetiségú - munkaerő foglalkoztatása magyaráz (Borbély 2015).

A statisztika és a kutatások is jelzik, hogy Magyarország elvesztette vonzerejét a romániai migránsok számára, azonban valószínűsíthető, hogy több romániai idénymunkás dolgozik a mezőgazdaságban, mint amennyit az NFSZ statisztika tükröz. Ezt támasztják alá a statisztikában megjelenő, meglepően alacsony településszám, a kiterjedt, zöldség- és gyümölcstermesztésre szakosodott üzemekkel rendelkező települések feltűnő hiánya mellett tereptapasztalataink is: olyan településeken is találkoztunk rendszeresen visszatérő migráns napszámos brigádokkal, melyek nem jelentek meg a hivatalos statisztikában.

\section{MEZŐGAZDASÁGI IDÉNYMUNKA ÉS MIGRÁCIÓ}

A mezőgazdasági termelés szezonalitása a munkacsúcsok idején kiugró munkaerőigény gazdasági-társadalmi struktúráktól függetlenül szükségessé teszi az idénymunkát. A huszadik század elejére kialakult munkaszervezési formák hálózatba rendeződése biztosította a munkaerő kereslet és kínálat térbeli kiegyenlítését, munkáskezet a gazdaságok számára, és lehetővé tette a munkavállalók kilépését a szúk lokális munkaerőpiacról. A rendszereken átívelő kontinuitás mögött a két világháború között a mezőgazdasági munkaközvetítés intézményének hiánya, a szocializmus alatt a redisztributív gazdaságok egyik fogyatékossága, az állandósult munkaerőhiány húzódott meg (Katona 1961, Sárközi 1972, Lencsés 1981, Cséfalvay 1985).

A kilencvenes években a folytonosságot az etnikai jellegú migráció hálózataiban mozgó romániai idénymunkások biztosították. A szétesett és alakuló struktúrában jelentkező munkaerőgondok megoldásának alternatívájaként jelentkezett a romániai magyar vendégmunkások foglalkoztatása. A napszámosok foglalkoztatása biztosította az üzemek fennmaradását, megerősödését, a versenyképesség megtartását és azt a tudatot, hogy nyugodtan bekapcsolódhatnak a kilencvenes évek végén indult támogatott telepítésekbe, ${ }^{13}$ mert elérhető a betakarításhoz szükséges munkaerő. Másodsorban a foglalkoztatás alacsony költségét kell kiemelnünk, valamint a vendégmunkások munkafegyelmét, gondos munkavégzésüket, egyszóval munkakultúrájukat (Hamar 2014). A biztosnak tekintett munkaerő-utánpótlás bővülésével a vállalkozások idővel egyre több költséget hárítottak át a migránsokra, ez a folyamat már a kilencvenes években elindult. Általában egyre kevesebb munkaadó járult hozzá az utazási költségekhez, eltűnőben volt a napszámba kötelezően beleszámított ingyenes étkezés és az elszállásolás a termelő lakóházában. Ezzel párhuzamosan foszladozott a kezdetben még fontos nemzeti összetartozás-érzet, a paternalisztikus segítőkészség és a befogadás érzése is veszített jelentőségéből, mind mar-

13 Az első telepítési hullám 1998-tól az EU csatlakozásig tartott. A költségvetési forrásból nyújtott támogatás az ültetvények területének növelését, szerkezetátalakításának gyorsítását, még az EU csatlakozás előtt az ágazat helyzetének erősítését szolgálta. A telepítéseknél számos szakmai-technológiai hibát vétettek a termelők, mely a későbbiekben nehezítette a gazdaságos termesztést. A támogatott ültetvényterület nagyságáról nem áll rendelkezésünkre adat. 
kánsabb lett a „román stigma” (Feischmidt 2004), és ha a migráns nem volt megelégedve az ugyan ingyenes, de rendkívül alacsony színvonalú szállással, igénytelenebb napszámosokat kerestek. A nem gazdasági jellegú viszonyok kopásával, eltûnésével kezdett kialakulni a „tiszta” piaci kapcsolat a foglalkoztató és a munkavállaló között, és a bőséges munkaerő-kínálat lehetővé tette, hogy a termelők alacsonyan tartsák költségeiket (Ozsváth 1997, Fodor 2006).

Az ezredfordulóra már érezhetővé vált az etnikai jellegú munkaerő migráció visszahúzódása, mely folyamat nem volt független a külföldre irányuló romániai migráció strukturális átalakulásától. A schengeni területek vízum nélküli elérhetőségével, a bilateriális szerződések megkötésével a migráció tömegessé vált, szelektivitása csökkent, mert a külföldi munkavállalás már azok számára is elérhető volt, akik korábban a szükséges tőke (anyagi, kapcsolati) hiányában nem vállalhatták a migránslétet.

A magyar idénymunkapiacra belépő vendégmunkások összetételének változásában ellenkező irányú folyamat ment végbe az ezredfordulót követően: számuk radikálisan csökkent, szúkült a terület, ahonnan Magyarországra érkeztek, és átalakult etnikai és társadalmi összetételük is.

A kilencvenes évek végén Hargita, Kovászna, Maros, valamint Szilágy megyékben a visszatérő (cirkuláris) migránsok 70 százalékának elsődleges célországa Magyarország volt. De Kolozsban már csak 26, Biharban 14 százalékról mondható el ez, míg Szatmár és Arad migránsai körében nem szerepelt Magyarország az első három célország között (Sandu 2002, Sandu et al. 2004). A kilencvenes években a napszámosok fő területi merítő bázisát a hagyományosan munkaerőt kibocsátó Hargita, Maros és Kovászna megyék mellett Szatmár, Bihar és Arad megyék biztosították (Németh-Csite-Jakobi 2009). Az ezredfordulóra ez a bázis jelentősen összeszűkült, és az utánpótlás döntőrészt Bihar és Maros megyékre koncentrálódott.

Lassú változás ment végbe a munkások kor szerinti összetételében is. Más országokban munkát vállaló társaikhoz hasonlóan a napszámos migránsok is a fiatal, falun élő korcsoportokból kerültek ki. A határok átjárhatóságával a két ország jövedelemszintje közötti különbség miatt a munkaerőhiány csökkentéséhez bőségesen állt rendelkezésre munkáskéz (Gagyi 2002, Bodó 2009, Bertalan 1997). A termelőkkel, valamint a munkaszervezővel készített interjúkból tudjuk, hogy a nagyobb termelők megengedhették maguknak, hogy csak a legértékesebb, legjobban terhelhető 24 év alatti magyar jelentkezőket foglalkoztassák. Az évezred első éveiben érezhetően csökkent a fiatal munkavállalók száma, és hiába emelték folyamatosan a felső korhatárt, a magyarországi idénymunka már elvesztette vonzerejét. A jogi és strukturális problémák ellenére a kilencvenes évek végén kezdett megszilárdulni a román-spanyol migrációs csatorna (Moreh 2014), és a schengeni területek elérhetőségével megnyíltak a nyugati országok kedvezőbb fizetést nyújtó munkaerőpiacai, melynek hatására a magyar termelők végleg elvesztették a napszámos-utánpótlás biztosnak vélt bázisát. A romániai magyarok bekapcsolódtak a románok mediterrán országokat célzó hálózataiba, a rövid vagy hosszú távú magyarországi munkavállalás már csak a szegények, nincstelenek törekvése maradt (Sandu 2002, Gödri 2010).

Az etnikai jellegű migráció lecsengése a kétezres évek kezdetére esik, mely egybeesik az idénymunkára jelentkező romániai magyar etnikumú napszámosok számának apadásával is. A magyarországi munkaerőpiac már csak az alacsony iskolai végzettségü, szakképzetlen, gyenge anyagi háttérrel és nem vagy nehezen konvertálható tőkefajtákkal rendelkező falusi munkavállalói csoportokat vonzotta, melyekben felülreprezentáltak 
voltak a romák (Sandu 2002, Sandu et al. 2004, Ciombanu 2010, Kiss 2010). Az idénymunkában a magyarok helyét fokozatosan romániai magyar és román nyelvű cigányok veszik át, és Románia EU-csatlakozása után már ők határozzák meg a csökkenő számú vendégmunkások etnikai összetételét: a román munkaerőpiacról kiszorult vagy arra be sem lépő, tartósan munkanélküli, alacsony iskolai végzettségű, a többségi társadalomba eltérő mértékben integrálódó munkavállalók különböző csoportjai mozognak az idénymunka piacán.

\section{NAPSZÁMOSOK ÉS ÁLLANDÓ DOLGOZÓK - A HÁLÓZATOK ERODÁLÓDÁSA}

A migrációt elősegítő személyközi kapcsolati hálózatok a társadalmi tőke (vagy kapcsolati tőke) forrásaként elősegítik a migrációs döntés meghozatalát, elérhetővé teszik a szükséges információt, csökkentve a migráció kockázatát (költségeit). Massey és szerzőtársai (2002) a migráns hálózatokat rokoni, baráti, valamint az azonos származási közösséghez tartozáson keresztül kialakult kapcsolatokra épülő kapcsolatrendszerként írják le, amelyek a migránsok, a célországban élő korábbi migránsok, valamint a potenciális migránsok (származási országban élők) között szövődnek (Sik 2012, Gödri 2007). A hálózat nyújtotta előnyöket a migrációba később bekapcsolódók élvezhették, melyek kialakításában meghatározó szerepet vállaltak az elsők között érkezők (Bertalan 1997, Hamar 2014, Ozsváth 1997, Gagyi 2002, Bodó 2009). A hálózatok szerepe különösen az ezredforduló után vált újra fontossá, mert a magyar nemzetiségú munkások munkapiacról való eltűnésével keletkező vákuumba benyomuló csoport nem vagy alig rendelkezett konvertálható tőkével és nem jutott hozzá a már kiépített hálózatok nyújtotta előnyökhöz sem. Ebben a helyzetben kulcsszereplővé vált - munkásszervezéssel foglalkozó ügynökségek hiányában - a fogadó üzem szervezői (ügynöki) feladatot is ellátó munkavezetője.

A kedvezőbb nyugat-európai munkalehetőségek elérésével a migránsokat közvetítő hálózatok egy része felbomlott, a megmaradtak differenciálódása felerősödött, jellegében változott, míg új hálózat kialakulásának egyre kisebb lett az esélye. A fejezet az interjúk alapján, de interjúrészletek nélkül, egy absztraktabb szinten írja le a különböző hálózatokat (és a benne mozgó munkásokat), melyek időbeli metszeteként a hálózatok változásának, erodálódásának egy-egy szakaszaként is értelmezhetők.

Nyolc interjú készült munkásokkal, a négy nő és a négy férfi a 30-40 éves generáció képviselői, az egyetlen idős nő (67 éves) már nem vállal napszámot. Szocio-ökonómiai jellemzőik szerint két, markánsan eltérő csoporthoz tartoznak. A Bihar megyei kisváros elitjéhez (polgármester testvér, főépítész apa) kötődők magyar nemzetiségűek. Érettségi után szakmát tanultak vagy egyetemre jártak, melyet az elhelyezkedés kilátástalansága miatt abbahagytak. A kilencvenes évektől rendszeresen vállaltak idénymunkát, most a gazdaság alkalmazottjai. Kettős állampolgárok, családosok, a faluban élnek. A Maros megyei falvakból származók magyar cigányok. Rokonok (anya, testvérek, élettárs), a kiterjedt rokonság (klán) magját a nyolcgyermekes szülői család alkotja, a hálózat irányítását a gyerekeik közül a Magyarországon dolgozók vették a kezükbe. Tanulmányaikban nem jutottak tovább az általános iskola néhány osztályánál, egyetlen férfi iratkozott be szakmunkásképzőbe, melyből végül kimaradt. A kilencvenes évek elejétől vállalnak napszámot a településen. Kettős állampolgárok, gyereket nevelő családosok.

A tizenkét termelő összetételében jelen vannak a volt nagyüzemek kertészeteinek vezetői, a pályakezdő kertészek (kertész/agrármérnök) éppúgy, mint a nyolcvanas években már 4-6 hektáron „háztájizó”, iparosból 
lett gazdálkodó, vagy az erdészeti vállalkozásának hasznát gyümölcsültetvénybe forgató vállalkozó. A legnagyobb gazdaság 120 hektár gyümölcsössel rendelkezik, a skála másik végét a nyolc hektár meggyes foglalja el.

\section{Stabil hálózatok és napszámosok}

A kilencvenes évek fordulójától romániai magyarok, csángók, cigányok és románok kínálták munkaerejüket magyarországi gazdaságoknak. Az alkalmi munkaerő elosztását végző lokális piacok az ezredfordulóra visszaszorultak, elvesztették jelentőségüket (Sik 2010), a migránsok mozgását, a napszámosok elérhetőségét a stabilizálódott kapcsolathálózatok tették lehetővé. A termelői és a napszámos interjúkból tudjuk, interjúk alapján elmondható, hogy a hálózatok folytonossága nemcsak viszonylagos biztonságot, kiszámíthatóságot adott a munkavállalók és a termelők számára, hanem idővel állandó alkalmazást is a kiválasztott szerencsések részére.

A termelők hívták fel a figyelmet a folytonosságra, amit a szocializmus alatt kialakult nemzetközi építőtábori kapcsolatrendszer továbbmúködtetése nyújtott a kezdődő és a kilencvenes évtized végére megszűnő intézményesüléssel.

Az átalakult mezőgazdasági nagyüzemek utódszervezeteinek menedzsmentje erre a kapcsolatrendszerre építette fel az ügynökségi funkciót ellátó, munkaerő-elosztó hálózatot. A romániai kapcsolattartók végezték a toborzást, egy magyarországi szervezet (diákszövetkezet) intézte a munkavállalási engedélyt és a munkaerő üzemek közötti elosztását is. Az ezredfordulóra a munkaerő intézményesített utánpótlása megszűnt, de addigra a nagyobb ültetvényekkel rendelkező üzemek már megszilárdították hálózataikat, amelyek átvészelték a munkaerő-kínálatban jelentkező változásokat is. A folytonosság lehetővé tette a stabil, visszatérő munkásgárda kialakulását, melynek alapja a környező üzemekhez viszonyítva magasabb bér, legális, munkavállalási engedélylyel és szerződéssel biztosított munkavégzés és a mindig kifizetett kereset volt.

Az interjúkból tudjuk, hogy a megbízható napszámosok közül kerültek ki napjainkra az állandó alkalmazottak: munkavezető, adminisztrátor/bérszámfejtő, targoncavezető, hűtőházkezelő, valamint a fizikai munkát végzők (brigádvezetők, metszést, csomagolást, áruelőkészítést végzők). Található közöttük diplomás, érettségizett, szakmunkás (pl. vegyészmérnök, gyümölcskertész), de legtöbben csak a kötelező alapfokú iskolát fejezték be. Sokan kettős állampolgársággal rendelkeznek és letelepedtek, a kétkezi munkások azonban megőrizték vendégmunkás státuszukat. Az üzem által fenntartott munkásszállón laknak, és két-háromhavonta vagy nagyobb ünnepekre utaznak csak haza, de nem akarnak „kijönni Romániából”.

Az interjúkból kirajzolódott az elmúlt egy évtized alatt kialakult szakadékszerü különbség a migránsból lett állandó alkalmazottak és a szezonra érkező foglalkoztatottak között. Vannak magyar napszámosok is, akiket a magyarországi munkaszervező, a „szállásadó” toboroz és oszt el a települések üzemei között, a napszámosok többsége azonban romániai cigány munkavállaló. A cigányok arányának emelkedésével szigorodtak a kiválasztás szempontjai is, többszöri szűrőn esnek át a cigánysághoz tartozó jelentkezők. Az alkalmasságra rá kell bólintania a kibocsátó települések polgármestereinek és a szegregált telepen élők választott vezetőinek is. Feltétel a magyar nyelvű kommunikáció képessége, a telepi romák esetében a vezető jelenléte az idénymunka alatt, valamint az érvényes erkölcsi bizonyítvány is. A válogatás szempontjai és mechanizmusa túlmutatnak a munkavégzésre alkalmas jelentkezők kiszürésén, a munkaszervezetbe betagozódni képes munkavállalók kivá- 
lasztásának eszközéül szolgálnak. Olyan emberekre van szükség, akik elfogadják a szervezeti hierarchiát - vagy rákényszeríthetők erre -, a kötött szabályokat, a vezetők döntéseit nem kérdőjelezik meg. Csak így csökkenthetők a konfliktusok, s így biztosítható a folyamatos munkavégzés.

Ami a szervezet számára a megbízható munkaerő elérését biztosítja, az többszörös alávetettséget, illetve függőséget jelent a napszámosok oldalán. Számukra a rugalmasság a szúkösen rendelkezésre álló források legkedvezőbb kombinációjának megtalálási-megtartási kényszerét jelenti (Váradi 2015, Ludescher 2013, Voiculescu 2004).

Az idénymunkából származó jövedelem a család legnagyobb bevétele az otthoni kisebb alkalmi munkák, gyüjtögetés vagy esetleges szociális transzferek mellett (Szabó 2013, Voiculescu 2004). Nincs ez másként a kisvárosból és térségéből érkező roma napszámosoknál sem, legtöbbjük számára a gyümölcsszedésből származó jövedelem a család egyetlen biztos bevétele. Így a „renitensek” is könnyen kordában tarthatók a lakóhelyük polgármesterének adott negatív visszajelzés lebegtetésével, valamint a munkások és a foglalkoztató között elhelyezkedő, konfliktushárító feladatot ellátó választott vezető jelenlétével. A megbízható napszámosok nemcsak teljesítménybérezésben dolgoznak, hanem az órabéres munkákhoz is hozzájutnak (pl. szamócaszedés), így a szezon számukra több hónapra is elhúzódik. A legjobb munkások a havi 150 ezer forintot is megkeresik (ennek egy részét zsebbe kapják), mégsincs reális esélyük arra, hogy a szezonmunka legnehezebb, legmegterhelőbb munkájából (gyümölcsszedés) előbbre léphessenek és a könnyebb, jobb körülmények között végezhető munkákkal bízzák meg őket. Az állandó alkalmazottá válás kitaposott útja (szedés, metszés, válogatás, mérés, csomagolás) számukra nem járható, mert a korábban érkező romániai magyar munkások elfoglalták ezeket a munkahelyeket, és azért sem, mert ha meg is felelnének a feltételeknek, a magyar nemzetiségú állandó alkalmazottak nem engednek be maguk közé romákat.

A napszámosok nem rendelkeznek a munkaszervezetbe betagozódáshoz és a munkavégzéshez szükséges kompetenciákkal (pl. a tartós „alávetettség” elfogadása, eszközök megfelelő kezelése, a munkavégzés rutinszerű ismétlődése). A hosszabb idejű és ismétlődő foglalkoztatásra annál nagyobb az esély, minél jobban megközelíti valaki az ideális napszámostól elvárt munkát, azaz hajnalban kel, végigdolgozza a napot, este holtfáradtan bemegy a szállásra az ágyára, hogy pihenjen. Ha azt mondják neki, hogy meg kell rakni egy kamiont vagy meg kell csinálni még egy sávot a gyümölcsösben, felkel, és szó nélkül megcsinálja.

A stabil hálózatok másik típusa a kisebb, de mégis jelentős területtel rendelkező egyéni gazdaságokhoz kapcsolódik. A romániai cigány napszámosok már a kilencvenes évek elején megjelentek az alföldi településeken, munkavállalási engedély nélkül, feketén foglalkoztatták őket. Ha az ellenőrzésen elbuktak, az országból való kitiltás időtartamának lejárta után újra próbálkoztak, és nem is eredménytelenül (Gagyi 2002). A termelőkkel készült interjúkból tudjuk, hogy az évente visszatérő napszámosok keresték a minél hosszabb szezont, biztosabb keresetet adó üzemeket, így nem számított ritkaságnak, hogy évente más-más gazdaságban dolgoztak. A rokoni kapcsolatban (klánok) álló idénymunkások egymáshoz közeli településen vállaltak munkát, az üzemek viszonylag kis munkaerőigénye miatt nem egy-egy gazdaságban koncentrálódtak. A magyar anyanyelvú napszámosok között volt, aki Romániában a szövetkezetek, állami gazdaságok megszűntével vált munkanélkülivé, de rendszeres visszajárók közé tartoztak a kereskedéssel, csencseléssel foglalkozó migránsok is. A nyári 
munkák alatt magukkal hozták a kisgyerekeket is, és ha a szezon belenyúlt az őszi hónapokba, nem számított ritkaságnak, hogy a gyerek csak a munkák befejeztével került haza és iratkozott be az iskolába (amit általában nem fejezett be).

A szülői generáció kapcsolatrendszere teremtette meg a stabil hálózatot, melybe a felnőtt (16-18 éves) gyerekek bekapcsolódtak, a szülők kilépése után ők váltak a hálózat mozgatóivá, ők rendelkeztek a szükséges információval, termelőkkel tartott kapcsolattal, amely elérhetővé tette a Romániában élő rokonok számára a biztos munkát a szezon alatt. A kapcsolatból profitált a termelő is, aki hozzájutott a szükséges számú megbízható munkáshoz, így a szezonális munka is tervezhető lett.

E vendégmunkás csoport helyzetében gyökeres változást az áttelepülés és a kettős állampolgárság hozott. Nem minden szülőt és gyereket vonzott a végleges áttelepülés lehetősége, az idősebbek ragaszkodnak megszokott környezetükhöz, a családos fiatalok csak a nyári munkákra jöttek át. Az áttelepülés mellett döntő szülők lepusztult állapotú tanyát vásároltak és/vagy a napszám, alkalmi munkák mellett szamócatermesztéssel, lókereskedéssel foglalkoznak. A felnőtt gyerekek számára egy-egy erősebb gazdaság biztosított munkát és egzisztenciális hátteret, a termelővel kialakult kapcsolatukat a patrónus-kliens (Kuczi 2011, Vigvári 2015) és a gazda-kommenciós cseléd viszonyának sajátos egyvelege jellemezte. Az utóbbira jellemző, hogy a gazda tanyájában laknak, lakbért nem, csak az áramot kell fizetni, ingyen kapnak tüzelőt, van, akinek munkaadója saját állományából egy malacot ad és a hízóvá neveléshez szükséges takarmányt is biztosítja számukra. A juttatásokért cserébe a gazdaság körüli mindennapi teendőket is ellátják (állatok etetése, kisebb munkák). A patrónus-kliens viszony tetten érhető a hivatalos ügyek intézésében nyújtott segítségben, a helyi viszonyok ismeretére épülő információ átadásában (pl. egy leromlott tanya megvételéhez), vagy a meghívásban és részvételben a gazda születésnapi ünnepségén. A patrónus-kliens viszony fenntartásának, megerősítésének leghatékonyabb eszköze a kölcsön, mely mind a termelőnek, mind a napszámosnak előnyös. A téli hónapokra félrerakott 200-250 ezer forint szigorú beosztás mellett sem elég a család megélhetéséhez. A gazdától kapott (havi) 10-15 ezer forintos kölcsönt ledolgozzák, és csak részletekben kell visszafizetni a nyári hónapokban. Az aszimmetrikus viszonyba a munkások a termelő iránti lojalitást, a munkavégzésben a megbízhatóságot és az idényben még szükséges többletmunkaerőt biztosító kapcsolati hálót viszik be.

Bár megélhetésük fő bázisa a gazdaság, munkaszerződésük nincs, az idény elindulásával egyszerűsített foglalkoztatottként regisztrálják őket. Nincs kőbe vésett megegyezés a fizetési határidőkről sem, általában hetente-kéthetente kapják meg bérüket, „,vagy amikor szükségük van rá”. Ha a gazdaságban nincs munka, a gazda elengedi őket dolgozni, hogy kereshessenek, gyarapodhassanak, vagy maga küldi át a munkásokat gazdatársához, hogy kisegítse őt. Az egyedülállók idényben a gazdaságban dolgoznak, télen megélhetésüket az erdészetnél vagy a Vízügynél közmunkásként végzett munkából biztosítják.

A település társadalmának perifériájához is gyengén kapcsolódó napszámosok számára az önálló ház vásárlása - legyen az egy kis tanya vagy egy elöregedő falu belterületén álló családi ház - vízválasztónak bizonyul, mely nemcsak a jobb anyagi helyzetet jelzi, hanem a felemelkedéshez szükséges mozgástér fokozatos bővítését is lehetővé teszi. Az anyagi gyarapodás legbiztosabb útja a napszámosként megtanult termesztési eljárások hasznosítása, melyhez viszonylag kis anyagi ráfordítással lehet hozzákezdeni és fokozatosan bővíteni (pl. eper- 
termesztés) belterületi telek, vagy a tanya melletti föld bérlésével.

A termelői és napszámos interjúkból megismert stabil hálózatok a kilencvenes években alakultak ki, és folytonosságuk, stabilitásuk megőrzésében meghatározó szereppel rendelkeznek a közvetítő funkciót ellátó munkaszervezők, akik maguk is migráns munkavállalók voltak. A munkaszervezők napjainkban sem független, az üzemek között munkaerőt elosztó vállalkozók, hanem egyetlen üzemhez kapcsolódnak mint alkalmazottak/ állandó napszámosok. A hálózatot az üzemhez (foglalkoztatóhoz) kötő, mozgató, szelektáló szervező számára - függetlenül nemzetiségétől és iskolai végzettségétől - gazdaságilag és társadalmilag is emelkedést biztosít a magyarországi munkahely, üzemen belüli helyzetét erősíti a rendelkezésére álló kapcsolati tőkéje. A termelőhöz nem csak a munkahely köti őket, hanem erős lojalitás is.

A rokonsági vagy területi elven szerveződő hálózatok térbeli kiterjedtségét a szükséges munkaerő nagysága és a szervező romániai település lokális társadalmában elfoglalt helye, kapcsolatrendszere határozza meg. A kisebb üzemek számára idénymunkást biztosító hálózat zárt, nem lépi át a rokoni kapcsolatokat. Előnye rugalmassága, a munkások megbízhatósága, munkakultúrája, a rokonsági csoport viselkedést szabályozó kontrollja. Azonban hátránya is zártságában keresendő, mely elegendő számú munkás hiányában meggátolja az üzem termelési volument növelő törekvését. A térben kiterjedt hálózat szervezője is teljes kontroll alatt tartja a szervezést, azonban a lokális társadalomban elfoglalt helye, kapcsolatrendszere, a munkásokhoz való viszonya és a szervezés módja gyökeresen eltér a zárt hálózatot múködtetőtől. A szakképzett, a többségi társadalomhoz tartozó szervező rokoni, ismerősi kapcsolatrendszerén keresztül mozgatja a több településre kiterjedő, a többségi társadalomba eltérő mértékben integrálódó, szegregáltan élő romák toborzását. A rokonsági kontrollt felváltja a többlépcsős ellenőrzésre épülő szelekció, melybe a helyi hatalmi viszonyokat tükröző formális és informális intézményeket is be tudja kapcsolni.

\section{Instabil hálózatok és napszámosok}

Az első támogatott telepítési hullám ültetvényei az ezredfordulót követő években kezdtek termőre fordulni, így a vendégmunkások számának lassú, de megállíthatatlan csökkenése érzékenyen érintette a termelőket, különösen azokban a térségekben, ahol kevés volt a hazai napszámos. A kiépített hálózatok sérülékennyé, a termelők számára sokszor kiszámíthatatlanná váltak a romániai magyar munkaerő kilépésével. A magyarokat fokozatosan váltották fel a romániai cigány munkavállalók, akik a munkaerőhiányos térségekben az elmúlt közel tíz év alatt váltak az idénymunka piacának fontos szereplőivé. A nagyobb termelők maguk láttak hozzá új hálózatok kiépítéséhez, illetve a vendégmunkások kapcsolatrendszerére épülő bővítéshez, a kisebb termelők családokkal, klánokkal építettek ki kapcsolatot. A munkaerő-utánpótlás csak részben érkezett szervezetten, sokan rákényszerültek/nek a vándorló, munkát kereső csoportok felfogadására, a szerencsére bízva magukat. A kilencvenes évek vendégmunkásaitól kultúráját, társadalmi és munkaerő-piaci integrációját illetően gyökeresen különböző munkavállalói csoportok jelentek meg az idénymunka piacán, melyek felett a munkaerőgondokkal küzdő termelőknek nem vagy alig van befolyása. A munkaerőt az üzemek között elosztó szervező hálózatán érkező fiatal és fiatal középkorú, döntőrészt férfiakból álló csoportok mellett a fő utánpótlást a napjainkra már fogyatkozó számú vándorló családok jelentik. A kisgyerekeket is magukkal hozó, elhagyott, pusztuló tanyákba 
behúzódó, kapcsolatok és anyagi források nélküli családok általában a nagy ültetvényeken találnak munkát, azonban néhány nap elteltével továbbállnak, ha nem kapnak előleget, akkor még hamarabb.

A térbeli mozgás nemcsak a vándorló családok jellemzője, a hálózathoz tartozó napszámosok térben követik a dömpingmunka iránti keresletet. Tavasszal a csongrádi spárgatermelőknél kezdenek, a szamóca, a cseresznye és a meggy érését követve jutnak el Bács-Kiskun megyén keresztül Pest megyébe. A vándorlásban szerepet játszanak, ha közvetett módon is, a zöldség-gyümölcstermelők értékesítő szervezetei, amelyek a felszabadult munkaerőt tagjaik között informálisan elosztó intézményként funkcionálnak. A meggy betakarítása után Kecskemét térségének szilvaütetvényei biztosítják számukra a megélhetést, esetleg ősszel a szövetkezetekben a fizikai munka (válogatás, csomagolás).

A munkásszállássá átalakított, berendezett épületekben, tanyákon elszállásolt migránsok termelők általi megítélése ambivalens. Általános problémaként említik a magas fluktuációt, a munkások alacsony munkakultúráját, azt, hogy a munkások semmibe veszik a szabályokat, rövid idő után előleget kérnek, igénytelenek a lakókörnyezettel szemben - sok szállás felszereltsége, állapota eredetileg is nagyon igénytelen - és könnyen felrúgják a megállapodásokat. Ebben nem kis szerepet játszanak maguk a termelők is; egyrészt a munkások számára a nagyobb területű, több munkalehetőséget kínáló gazdaságok tagadhatatlanul nagyobb vonzerővel bírnak, másrészt jellemző a munkásokért folytatott verseny, az a konfliktusokat is gerjesztő gyakorlat, hogy a munkavállalók átcsábítják egymástól a munkásokat. Kivételnek számít az a termelő, aki elégedett az évente visszatérő munkások teljesítményével, munkakultúrájával, akik megfelelnek a munkaadók egyetemleges elvárásainak: az ültetvényen folyamatosan dolgoznak, a munkát nem szakítják félbe cigarettaszünetek, nem isznak, a csoportban fegyelmet tart a vezető, nem állnak tovább néhány nap után, és vigyáznak a munkásszállás berendezésére. ${ }^{14}$

A napszámbérek területi különbségei, ${ }^{15}$ a termelők törekvése a bérek alacsonyan tartására és a munkaerőhiány kényszerítő ereje, valamint a munkások más térségekben szerzett munkavállalási tapasztalatai együtt alakítják a béreket. Még egy évtizeddel korábban is a külföldi idénymunkások a hazai napszámosoknál olcsóbban dolgoztak. Míg 2006 táján, a térségben munkát kereső, nem szervezett roma idénymunkások megjelenésekor „egy tál ételért is vállalták a munkát”, most már előfordul, hogy választás elé állítják a termelőt: vagy magasabb bért fizet, hogy a minőségi követelményeknek megfelelő munka ne lassítsa a munkateljesítményt, vagy más gazdaságban próbálnak szerencsét. A napszámosokért folytatott versenyben a megbízható migránsokkal kapcsolatot tartó termelők a térségi átlagnál magasabb bér fizetésével igyekeznek munkásaikat magukhoz kötni, ami a munkaerő szelektálásának, a stabil hálózat kialakítására törekvésnek a biztos jele.

14 Hasonló elvárásokat fogalmaznak meg a spanyol munkaadók is az „ideális” vendégmunkással szemben (Mannon et al. 2012).

15 A napszámbérekben jelentős regionális különbségek vannak: legalacsonyabb bért a Szabolcs-Szatmár-Bereg megyei termelők fizetnek, a legmagasabb napszámért Pest megyében dolgoznak a munkások (lásd Hamar 2016). 


\section{ÖSSZEFOgLALÁS}

A tanulmányban a romániai vendégmunkások magyar idénymunkapiacon elfoglalt helyével és szerepével foglalkoztam. A kilencvenes években szerveződő magyar idénymunkapiac helyzetét jelentősen befolyásolta a romániai munkaerő-piaci migrációs trend változása. A kilencvenes években bőségesen rendelkezésre álló migráns munkaerő számának apadásával a migrációt elősegítő hálózatok átalakultak: differenciálódtak, meggyengültek vagy felbomlottak. A napjainkban is tartó erodálást nem a létszám, hanem a napszámosok etnikai és társadalmi összetételének változása, a többségi társadalomba és a munkaerőpiacra gyengén integrálódott roma munkavállalók növekvő jelenléte generálta.

Az áttelepült, egykori migránsok kapcsolathálói biztos csatornái az erősen szűrt vendégmunkásbrigádoknak, a kilencvenes években gyökerező, a változásokhoz alkalmazkodó hálózatok fennmaradásukat a szelekciós mechanizmusok változásának, a munkaszervezetbe betagozódni képes munkások elérésének és megtartásának köszönhetik.

Az általam stabil hálózatnak nevezett kapcsolathálók kialakulása a kilencvenes években gyökerezik, folytonosságuk ellenére differenciálódtak, mely mögött az áttelepült migráns munkaerőt szervező, közvetítő kapcsolati tőkéjének felértékelődése, valamint a szervezetbe tagozódása húzódik meg. Két, markánsan elkülönülő típus rajzolódott ki. A kisebb üzemekhez kapcsolódó, rokoni-vérségi kapcsolatokra épülő hálózatok zártak, a hálózatba kerülés, mozgás szabályait (a szelekciót) a rokoni kötelékek normái szabályozzák. Míg a nagyobb üzemekhez kapcsolódó hálózatok központi szereplője az áttelepült migráns munkaszervező, aki rokoni kapcsolatait meghaladva intézményi-hatalmi ellenőrzés eszközeit is felhasználja a számára szükséges létszámú munkás eléréséhez.

Az instabil hálózatban mozgó, csökkenő számú vendégmunkások kiválasztása, az üzemhez kötésük megerősítése még napjainkban is tart. A hálózatok kialakulását, stabilizálását nehezíti a munkások gyenge munkafegyelme, a munkásokért folytatott verseny, valamint az idénymunkások gondolkodásából (kultúrájából) hiányzó igény a kapcsolattartásra, a kiszámíthatóságra és az információ megbízható áramlására.

Míg az instabil hálózatokhoz tartozó migránsok felett a termelők nem vagy csak igen gyenge ellenőrzéssel rendelkeznek, a stabil hálózatokban az áttelepült magyar nemzetiségú vendégmunkások számára az üzemek állandó alkalmazást biztosítanak, a cigány etnikumúakat a lokális munkaerőpiacra jellemző, eltérő mélységű és kiterjedésű patrónus-kliens viszony fenntartásával kötik magukhoz.

Habár a romániai idénymunkások száma folyamatosan csökken Magyarországon, de azokban a térségekben, ahol nem áll rendelkezésre megfelelő számú hazai munkaerő, továbbra is fontos szereplők maradtak. 


\section{HIVATKOZÁSOK}

Andrzejewska, J. - Rye, J. F. (2012) Lost in Transnational Space? Migrant Farm Workers in Rural Districts. Mobilities, 2, $247-268$. http://dx.doi.org/10.1080/17450101.2012.654996.

Bertalan B. (1997) Feketemunka importból, avagy a hétköznapi diplomácia eredete. In Sik E. (szerk.) Migráció és politika. Budapest: MTA PTI, 121-134.

Bodó J. (2009) A vendégmunka típusú migráció magatartásmintái a székelyföldi térségben (2. rész). Fórum Társadalomtudományi Szemle, 1-2, 117-135, 41-58.

Borbély S. (2015) „Az ukrán, utolsó cigány” - A külföldi bevándorlás mikropolitikája egy határvidéki településen, Kispaládon. Tér és Társadalom, 3, 3-32. http://dx.doi.org/10.17649/TET.29.3.2708.

Ciombanu, R. O. (2010) Migrációs minták két romániai falu elvándorlásában. Két esettanulmány tanulságai? In Hárs Á.-Tóth J. (szerk.) Változó migráció - változó környezet. Budapest: MTA Etnikai-nemzeti Kisebbségkutató Intézet, 125-146.

Cséfalvay Z. (1985) „Szocialista summások” Nagyvisnyón. Kultúra és Közösség, 3, 8-19.

Feischmidt M. (2004) A határ és a román stigma. In Kovács N. - Osvát A. - Szarka L. (szerk.) Tér és terep. Tanulmányok az etnicitás és az identitás kérdésköréböl, III. Budapest: Akadémia Kiadó, 43-58.

Fodor F. (2006) Romániai vendégmunkások a Duna-Tisza közi homokhátság paraszti gazdaságaiban. In Bathó E. - Újváry Z. (szerk.) Jászok és kunok a magyarok között. Ünnepi kötet Bánkiné Molnár Erzsébet tiszteletére. Jászberény: Jász Múzeumért Alapítvány, 423-428.

Fox, J. (2005) Vándorló nemzet(i) identitások. Erdélyi vendégmunkások Magyarországon. In Feischmidt M. (szerk.) Erdély-(de)konstrukciók. Budapest-Pécs: Néprajzi Múzeum - PTE Kommunikáció- és Médiatudományi Tanszék, 103-122.

Gagyi J. (2002) „'90 után nyilatkozott”. In Bodó J. (szerk.) Helykeresők? Roma lakosság a Székelyföldön. KAM-Regionális és Antropológiai Kutatások Központja, Csíkszereda: Pro-Print Kiadó, 89-100.

Gödri I. (2004) Etnikai vagy gazdasági migráció? Az erdélyi magyarok kivándorlását meghatározó tényezők az ezredfordulón. Erdélyi Társadalom, 1, 37-54.

Gödri I. (2007) A kapcsolati tőke szerepe a magyarországi bevándorlásban. Kisebbségkutatás, 4. Elérhető: http://epa.oszk. hu/00400/00462/00036/1510.htm [Letöltve 2015-10-07]

Gödri I. (2010) Bevándorlás és etnicitás összefüggések nyomában. In Hárs Á. - Tóth J. (szerk.) Változó migráció - változó környezet. Budapest: KTI, 87-124.

Hamar A. (2014) „Mi lenne nélkülük...?! Külföldi és hazai napszámosok egy Dél-Pest megyei kistérségben. In Nagy E. - Nagy G. (szerk.) Polarizáció - Függőség - Krízis - Eltérő térbeli válaszok. Békéscsaba: MTA KRTK, 18-28.

Hamar A. (2016) Idénymunka a zöldség-gyümölcs ágazatban. In Kovács K. (szerk.) Földböl élök. Polarizáció a magyar vidéken. Budapest: Argumentum Kiadó, 97-117.

Hárs Á. (2010) Migráció és munkaerőpiac Magyarországon. In Hárs Á. - Tóth J. (szerk.) Változó migráció - változó környezet. Budapest: KTI, 15-56.

Hárs Á. (2013) Az atipikus foglalkoztatás: mitoszok, lehetőségek és korlátok az atipikus foglalkoztatási formák lehetőségeinek kihasználásában. Budapest: Kopint Konjunktúra Kutatási Alapítvány. Elérhető: http://kopintalapitvany.hu/download/Atipikus_foglalkoztatottak_vallalati_vizsgalata_korr2.pdf [Letöltve 2015-11-17]

Katona I. (1961) Munkaszervezeti formák és ideiglenes életközösségek idénymunkákon a kapitalizmus korában. Agrártörténeti Szemle, $3-4,534-562$.

Kincses Á. (2012) A Kárpát-medence ezredforduló utáni migrációs hálózatának vizsgálata. Budapest: KSH.

Kiss T. (2010) Népszámlálás 2011: folyamatok és (köz)politikai irányok (Vitaindító). Magyar Kisebbség, 3-4, 7-38. Elérhető: http:// www.jakabffy.ro/magyarkisebbseg/pdf/002Vitaindito.pdf [Letöltve 2015-05-04]

Kuczi T. (2011) Kisvállalkozás és társadalmi környezet. Budapest: Jelenkutató Alapítvány.

Lencsés F. (1981) Mezőgazdasági idénymunkások a negyvenes években. Budapest: Akadémia Kiadó.

Ludescher G. (2013) Betekintés egy nyírségi cigány közösség életébe. In Szuhay P. (szerk.) Távolodó világaink. A cigány-magyar együttélés változatai. Budapest: Magyar Néprajzi Társaság, 301-311.

Martin, P. L. (1985) Migrant Labor in Agriculture: An International Comparison. International Migration Review, 1, $135-143$. http://dx.doi.org/10.2307/2545659.

Martin, P. L. (2003) Managing Labor Migration: Temporary Worker Programs for the 21th Century 40. Genova : International Institute for Labor Studies., Elérhető: www.un.org/esa/population/migration/turin/.../P07_Martin.pdf. 
Massey, D. et al. (2002) A nemzetközi migráció elméletei. Áttekintés és értékelés. In Sik E. (szerk.) A migráció szociológiája 1. E-tankönyv, Budapest:ELTE TáTK, 7-29.

Mannon, S. E. - Petrzelka P. - Glass Ch. M. - Radel, C. (2012) Keeping Them in Their Place. Migrant Women Workers in Spain's Strawberry Industry. International Journal of Sociology of Agriculture and Food, 1, 83-101. http://www.jstor.org/ stable/20455113.

Moreh, Ch. (2014) Alcalái románok. Migráció és társadalmi differenciálódás. Budapest: L’Harmattan.

Migrant seasonal worker. The impact on the horticulture and food processing sectors of closing the Seasonal Agricultural Workers Scheme and the Sectors Based Scheme. Migration Advisory Comittee (2013) London. https://www.gov.uk/government/ uploads/system/uploads/attachment_data/file/257242/migrant-seasonal-workers.pdf [Letöltve 2016-03-25].

Németh N. - Csite A. - Jakobi Á. (2009) Román állampolgárságú munkavállalók Magyarországon. Területi Statisztika, 6, 615-627.

Ozsváth G. D. (1997) Székelyek és csángók a csólyospálosi homoki gazdaságokban. In Juhász A. (szerk.) Migráció és anyagi kultúra a Duna-Tisza közén. Szeged: JATE Néprajzi Tanszék, 157-176.

Pulay G. (2005) A vendégmunka mint életforma. Széki építőmunkások Budapesten. In Feischmidt M. (szerk.) Erdély-(de)konstrukciók. Budapest - Pécs: Néprajzi Múzeum - PTE Kommunikáció- és Médiatudományi Tanszék, 143-162.

Sandu D. (2002) Emerging transnational migration from Romanian villages. Elérhető: http://www.migrationonline.cz/en/emergingtransnational-migration-from-romanian-villages [Letöltve 2015-02-20]

Sandu D. - Radu C. - Constantinescu M. - Ciobanu O. (2004) A Country Report on Romanian Migration Abroad: Stocks and Flows After 1989. Prága. Elérhető: http://aa.ecn.cz/img_upload/Romanian_Migration_Abroad.pdf [Letöltve 2015-02-20]

Sárközi Z. (1972) A summások. In Szabó I. (szerk.) A parasztság Magyarországon a kapitalizmus korában II. Budapest: Akadémia Kiadó, 321-381.

Sik E. (1996) Erdélyi menekültek Magyarországon. In Andorka R. - Kolosi T. - Vukovich Gy. (szerk.) Társadalmi Riport 1996. Budapest: TÁRKI, 516-533.

Sik E. (2010) Emberpiac a Moszkva téren: szúkülő változatlanság. In Czakó Á. - Giczi J. - Sík E. (szerk.) Piachely - KGST-piac - emberpiac. Budapest: Eötvös Lóránd Tudományegyetem, 343-374.

Sik E. (2012) A migrációs burok. In Sik E. (szerk.) A migráció szociológiája 2. E-tankönyv, Budapest: ELTE TáTK, $133-158$.

Szabó Á. T. (2013) Gazdasági adaptáció és etnicitás. Gazdaság, vidékiség és integráció egy erdélyi térségben. Kolozsvár: Nemzeti Kisebbségkutató Intézet Kriza János Néprajzi Társaság

Váradi M. (2015) A túlélés és a társadalmi betagolódás között: szegénység, kirekesztettség és kapcsolatrendszerek. In Virág T. (szerk.) Törésvonalak. Budapest: Argumentum, 45-68.

Vigvári A. (2015) Vissza a tanyákra - egy cigány család újrakezdési esélyei a szabolcsi pusztai világban. In Virág T. (szerk.) Törésvonalak. Szegénység és etnicitás vidéki terekben. Budapest: Argumentum, 211-227.

Voiculescu, C. (2004) Temporary Migration of Transylvanian Roma to Hungary. In Pop, D. (ed.) New Patterns of Labour Migration in Central and Eastern Europe. Cluj-Napoca: AMM Design,148-166. Elérhető: http://pdc.ceu.hu/archive/00003401/01/ temporary_migration.pdf [Letöltve 2015-02-20]. 